\section{RARE AND ENDEMIC TAXA OF LEUCAS (LAMIACEAE) IN INDIA}

\section{Priyanka Agnihotri ${ }^{1}$, Veena Dixit ${ }^{2}$, Harsh Singh ${ }^{3}$, Ajay Kumar Paliwal ${ }^{4} \&$ Tariq Husain ${ }^{5}$}

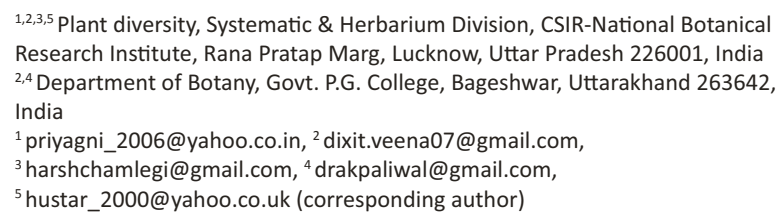

The genus Leucas R.Br. belonging to the family Lamiaceae (Labiatae) is comprising 98 taxa reported from different parts of the world (Sebald 1980), including 50 taxa from India (Singh 2001). Hooker (1885) in his Flora of British India included 34 species and 12 varieties from India. Later Mukerjee (1940) listed 43 species and 11 infra-specific taxa under the genus Leucas from India.

The adaptability of this genus can be seen as the populations grow equally well in the plains as well as in higher altitudes of the hilly regions of India. The genus Leucas is medicinally important as a whole and almost every species has unique medicinal value and are widely used by traditional healers in India as well as in other countries (Chouhan \& Singh 2011).

After thorough checking in important Indian herbaria as well as some foreign herbaria, Herbarium of Botanical Survey of India, Northern Circle, Dehradun (BSD), Herbarium of Indian Council of Forestry Research and Education, Dehradun (DD), Central National Herbarium, Kolkata (CAL), Herbarium of CSIR-National Botanical Research Institute, Lucknow (LWG), Herbarium of St. Xavier's College, Mumbai (BLAT), Herbarium of Central Drug Research Institute, Lucknow (CDRI), Herbarium of Botanical Survey of India, Southern Circle, Coimbatore $(\mathrm{MH})$, Herbarium of Presidency College, Madras (PCM), Herbarium of British Museum of Natural History, London (BM) and Herbarium of Royal Botanic Gardens, Kew (K) and also through scrutiny of

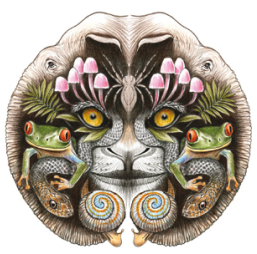

ISSN

Online 0974-7907 Print 0974-7893

\section{OPEN ACCESS} literature, 12 taxa of Leucas have been sorted out, 10 of which are known only by their type collections, while two taxa, namely, $L$. decemdentata var. angustifolia and L. eriostoma var. lanata have been collected only once after their type collections. Out of these 12 taxa, 11 are endemic to India, except $L$. decemdentata var. angustifolia (Image 3C) which is distributed in Nepal and was probably introduced from Gorakhpur in Uttar Pradesh. These species have also not been included in the Red Data Books of Indian Plants (Jain \& Shastry 1984; Nayar \& Shastry 1987, 1988, 1990). The taxa are listed below with notes on their distribution, flowering and fruiting months and herbarium details:

1. Leucas anandaraoana P. Umamaheswari \& P. Daniel in Kew Bull. 54: 1003. 1999; V. Singh in J. Econ. Tax. Bot., Add. Ser. 20: 36. 2001.

Leaves broadly ovate, $1-2.5 \mathrm{~cm}$ broad; bracts villous, as long as calyx. Calyx mouth pubescent, villi absent.

Distribution: Endemic to India (Tamil Nadu) (Image 1).

Flowering \& Fruiting: January-April.

Representative specimens: India: Tamil Nadu, Ramanathapuram, Gulf of Mannar Biosphere Reserve, Upputhanni Island, western side, 2m, 01.ii.1994, P. Daniel 101669A (holo.: CAL); P. Daniel 101669 B,C,D (iso. :MH, K) (Images 2 A,B).

2. Leucas angustissima Sedgw. in J. Ind. Bot. 2:

DOI: http://dx.doi.org/10.11609/JoTT.o3458.5507-11

Editor: Vijayasankar Raman, University of Mississippi, USA.

Date of publication: 26 February 2014 (online \& print)

Manuscript details: Ms \# 03458 | Received 26 December 2012 | Final received 31 January 2014 | Finally accepted 02 February 2014

Citation: Agnihotri, P., V. Dixit, H. Singh, A.K. Paliwal \& T. Husain (2014). Rare and endemic taxa of Leucas (Lamiaceae) in India. Journal of Threatened Taxa 6(2): 5507-5511; http://dx.doi.org/10.11609/JoTT.03458.5507-11

Copyright: (c) Agnihotri et al. 2014. Creative Commons Attribution 3.0 Unported License. JoTT allows unrestricted use of this article in any medium, reproduction and distribution by providing adequate credit to the authors and the source of publication.

Funding: Council of Scientific and Industrial Research, New Delhi under 12th five year plan.

Competing Interest: The authors declare no competing interests.

Acknowledgements: The authors are thankful to Director, CSIR-National Botanical Research Institute, Lucknow for providing necessary facilities and also CSIR, New Delhi for financial assistence under $12^{\text {th }}$ five year plan. We are also indebted to the curator and in-charge of CAL, BM and MH for providing type photographs. 


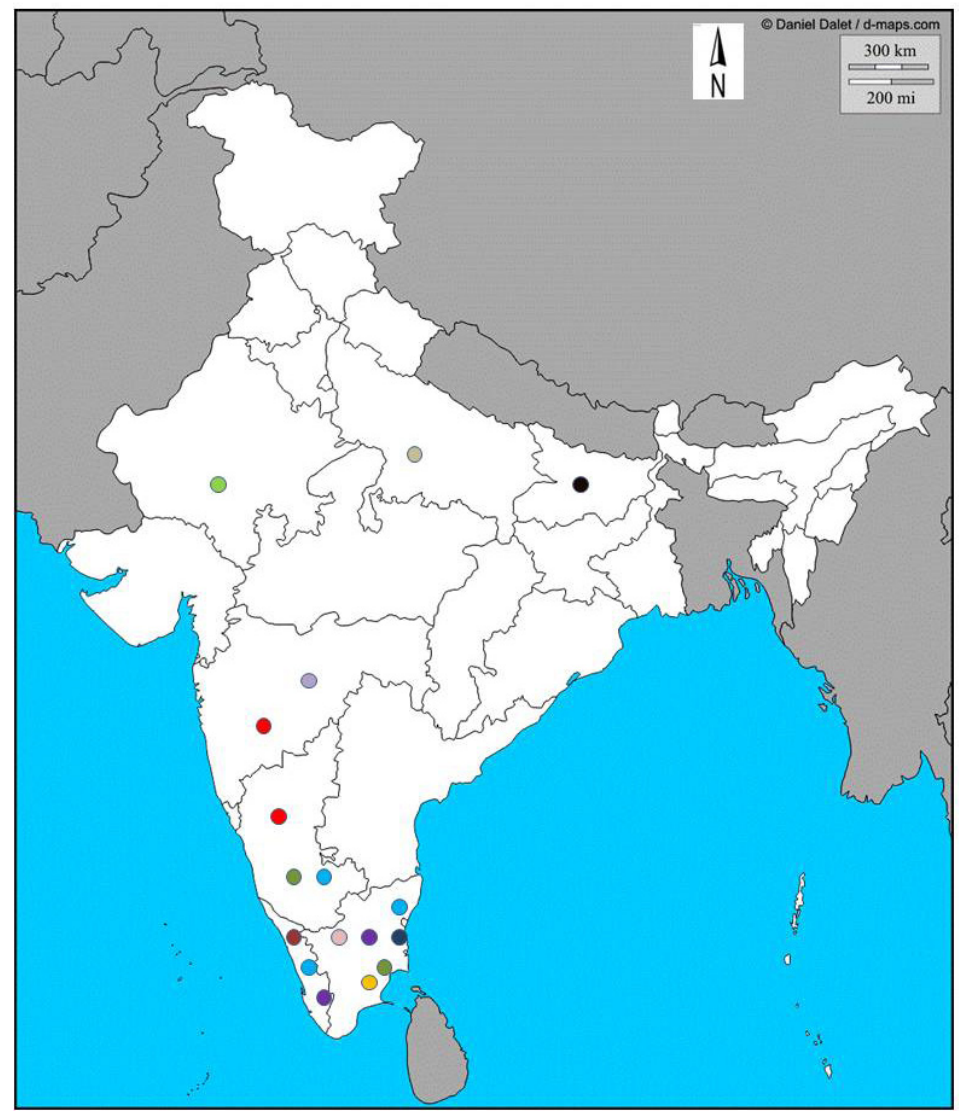

- Leucas anandaraoana

- Leucas angustissima

- Leucas decemdentata var. angustifolia

- Leucas deodikarii

- Leucas eriostoma var. lanata

- Leucas eriostoma var. Iatifolia

- Leucas helicterifolia

- Leucas beddomei

- Leucas macrantha

- Leucas vestita var. angustifolia

- Leucas vestita var. devicolamensis

- Leucas vestita var. sericostoma

Image 1. Map showing Type locations of Leucas species.

123.1921; V. Singh in J. Econ. Tax. Bot., Add. Ser. 20: 40. 2001.

Leaves linear, entire, revolute margined, upto $0.3 \mathrm{~cm}$ wide; bracts hairy, shorter than calyx. Calyx mouth oblique, villi absent.

Distribution: Endemic to India (Maharashtra \& Karnataka) (Image 1).

Flowering \& Fruiting: August-January.

Representative specimens: India: Maharashtra (Bombaiensi), Canara, Gairsoppa fall, 455m, November 1919, L.J. Sedgwick \& Bell 7234 (holo.: BLAT); L.J. Sedgwick \& Bell 7255 (para.: BLAT); Talbot 3740A (para.: BSI).

3. Leucas beddomei (Hook.f.) Sunojkumar \& $P$. Mathew in Rheedea 12(2): 169. 2002; Leucas hirta (Heyne ex Roth) Spreng. var. beddomei Hook.f., Fl. Brit. India 4: 687. 1885; V. Singh in J. Econ. Tax. Bot., Add. Ser. 20: 93: 2001.

Leaves linear-oblong. Calyx mouth villous; teeth longer than villi.

Distribution: Endemic to India (Karnataka, Tamil Nadu \& Kerala) (Image 1).

Flowering \& Fruiting: August-March.

Representative specimens: India: Kerala, Chambra
Peak, Wayanad, 1524m, R.H. Beddome s.n. (holo.:BM). (Image 3B).

4. Leucas decemdentata (Willd.) Sm. var. angustifolia (Benth.) V. Singh in J. Econ. Tax. Bot. 22: 388. 1998 \& in J. Econ. Tax. Bot., Add. Ser. 20: 74. 2001. Leucas angustifolia Benth. in Wall., PI. Asiat. Rar. 1: 62. 1830.

Leaves linear-lanceolate or narrowly lanceolate, 1.5 $\mathrm{cm}$ wide; Bracts shorter than calyx. Calyx mouth villous within.

Distribution: India (Uttar Pradesh), Nepal (Image 1).

Flowering \& Fruiting: July-March.

Representative specimens: India: Wall. Cat. no. 2064 (holo.:K); Uttar Pradesh, Gorakhpur, Dhomakhana forest, Jan. 1968, J.K. Maheshwari 81537 (LWG) (Image 3C).

5. Leucas deodikarii Billmore \& Hemadri in Indian For. 96 (12): 858. f. 1-4. 1970; V. Singh in J. Econ. Tax. Bot., Add. Ser. 20: 76. 2001

Leaves broadly ovate or ovate-lanceolate, $3-7.5 \mathrm{~cm}$ broad, acute, crenate; bracts linear-lanceolate, hairy along the margins, shorter than calyx. Calyx glabrous, veined within; mouth truncate, villi absent.

Distribution: Endemic to India (Maharashtra) (Image $1)$. 


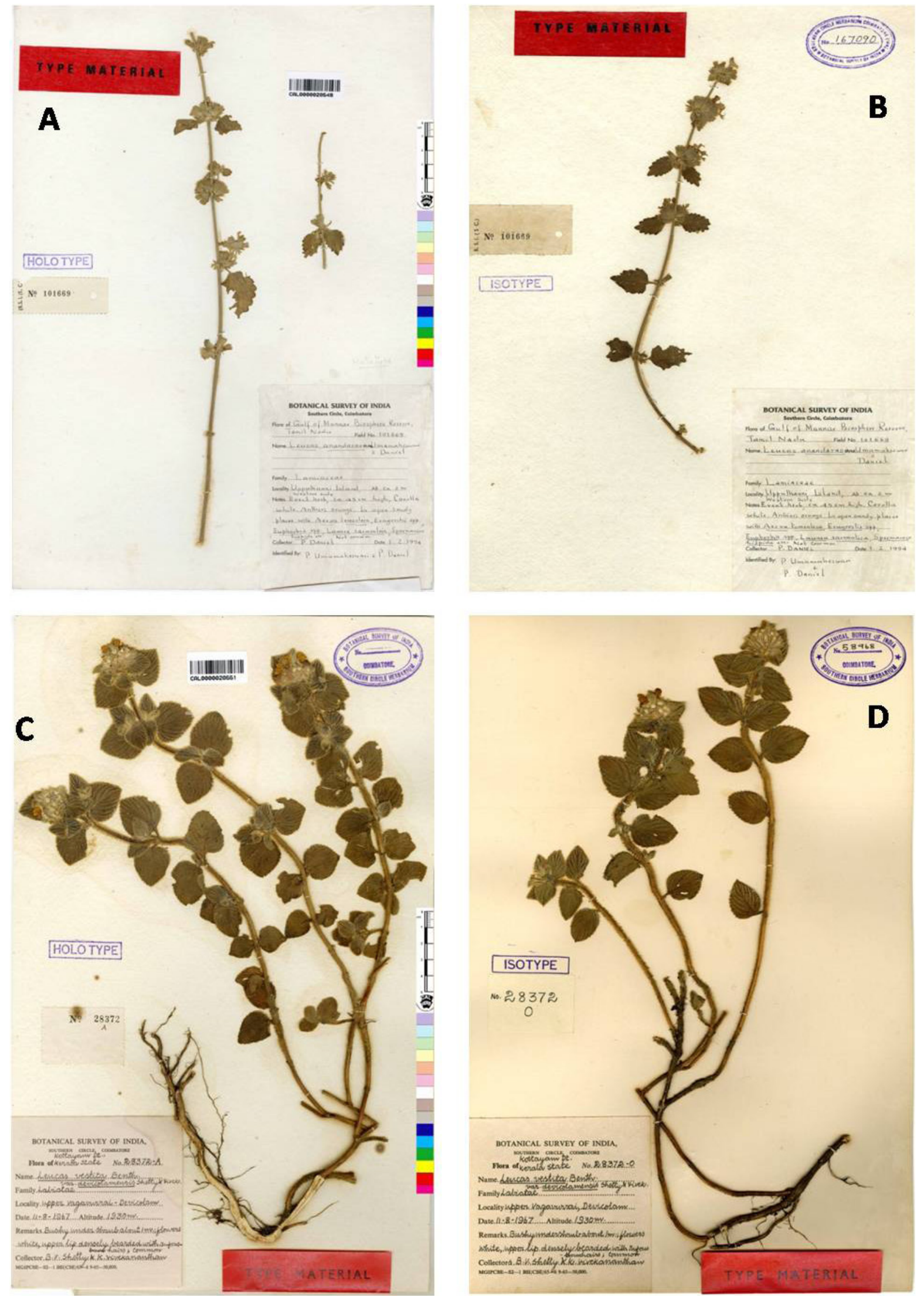

Image 2. Herbarium of Leucas anandaraoana (A - holotype; B - Isotype) and Leucas vestita var. devicolamensis (C - holotype; D - Isotype) 


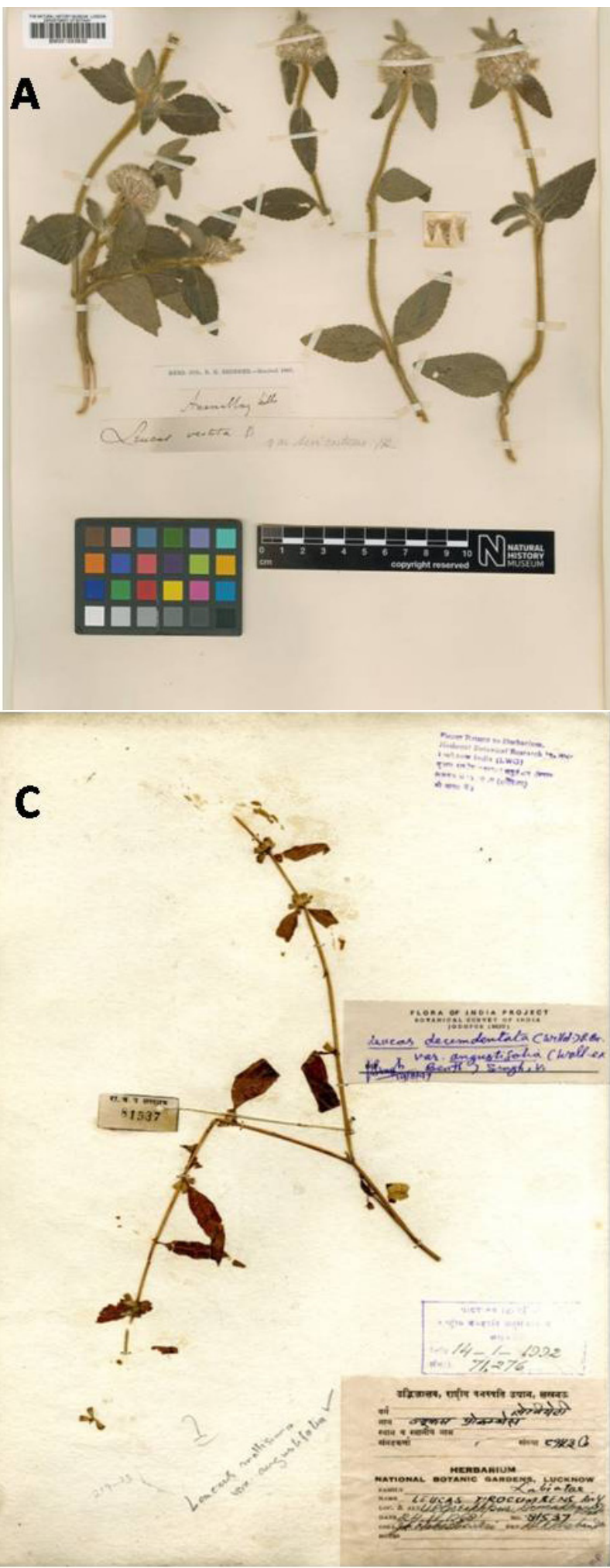

Image 3. Herbarium of Leucas vestita var. sericostoma (A), Leucas beddomei (B) and Leucas decemdentata var. angustifolia (C)

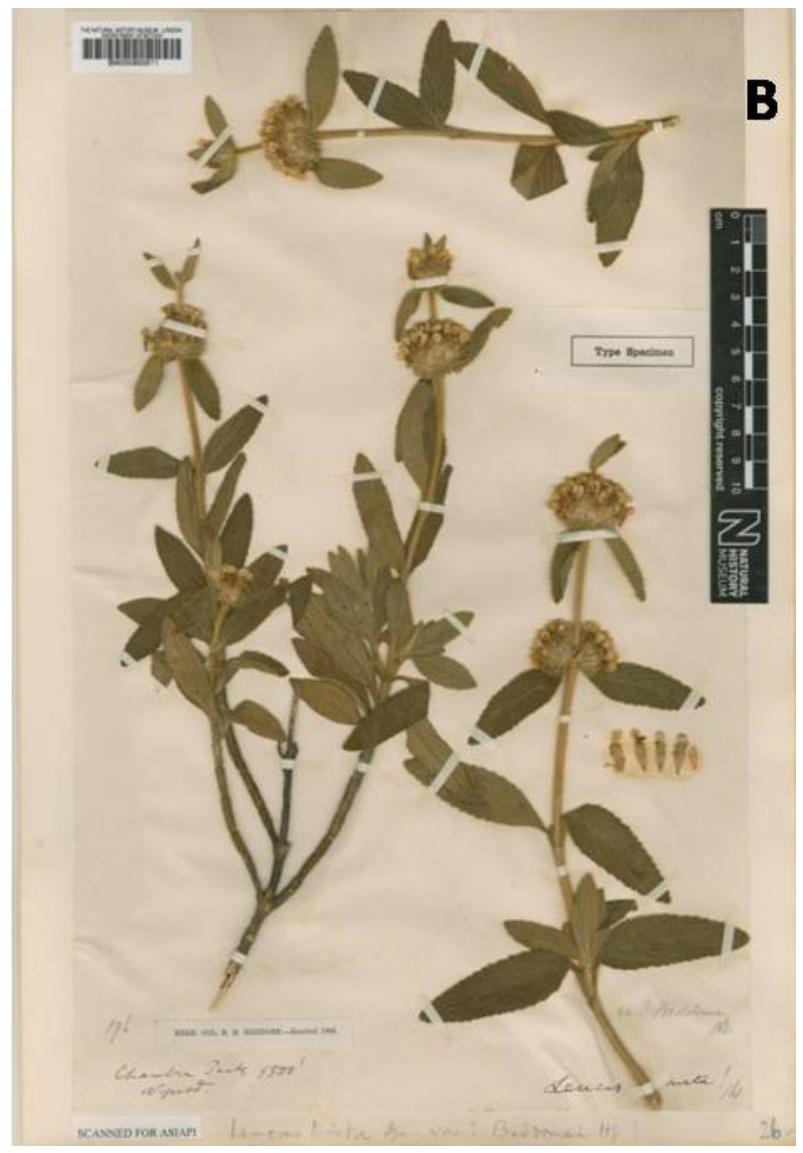

Flowering \& Fruiting: September-December.

Representative specimens: India: Maharashtra (Sahyadri range), Poona, 1100m., September 1968, K. Hemadri 117970A (holo.:CAL); K. Hemadri 117970 B-F (iso.:BSI), K. Hemadri 117970G (iso.: K).

6. Leucas eriostoma Hook.f. var. lanata Hook.f., Fl. Brit. India 4: 686. 1885; V.Singh in J. Econ. Tax. Bot., Add. Ser. 20: 84. 2001. Leucas eriostoma Hook.f. var. stocksii Hook.f., Fl. Brit. India 4: 686.1885.

Leaves oblong-lanceolate, $4 \mathrm{~cm}$ wide, villous on both surfaces. Calyx with a definite ring of villi; villi as long as or longer than calyx teeth.

Distribution: Endemic to India (Karnataka \& Tamil Nadu) (Image 1).

Flowering \& Fruiting: August-January.

Representative specimens: India: Karnataka, Mysore, Nilgiri and Badaboodan hills. Wight (holo.:E); Tamil Nadu, Salem, Servarayans, 1700m., 1962, E. Govindarajalu 4321 (iso.: PCM).

7. Leucas eriostoma Hook.f. var. Iatifolia Hook.f., Fl. Brit. India 4: 686. 1885; V.Singh in J. Econ. Tax. Bot., Add. Ser. 20: 86. 2001.

Leaves elliptic-oblong or lanceolate, $2.5-3.8 \mathrm{~cm}$ wide. 
Calyx mouth villous within.

Distribution: Endemic to India (Tamil Nadu) (Image 1). Flowering \& Fruiting: July-December.

Representative specimen: India. Wight (holo.:E).

8. Leucas helicterifolia Haines in Kew Bull. 1922: 188. 1922; V. Singh in J. Econ. Tax. Bot., Add. Ser. 20: 88. 2001.

Leaves lanceolate or oblong-lanceolate, $1.2-2 \mathrm{~cm}$ broad, villous on both sides; bracts pubescent, shorter than calyx. Calyx mouth truncate; villi absent.

Distribution: Endemic to India (Bihar) (Image 1).

Flowering \& Fruiting: November-December.

Representative specimen: India: Bihar, Ramnagar hills, 300-600 m. H.H. Haines 495 (holo.:K).

9. Leucas macrantha Blatt. \& Hallb. in J. Ind. Bot. 2: 47. 1921; V.Singh in J. Econ. Tax. Bot., Add. Ser. 20: 112. 2001.

Leaves lanceolate or linear-lanceolate, $0.8 \mathrm{~cm}$ wide; bracts hairy, as long as calyx. Calyx mouth oblique; villi absent.

Distribution: Endemic to India (Rajasthan) (Image 1).

Flowering \& Fruiting: September-December.

Representative specimen: India: Rajasthan, Mt. Abu, 1200m, October 1916. F. Hallberg 768 (holo.:BLAT).

10. Leucas vestita Wall. ex Benth. var. angustifolia Hook.f., Fl. Brit. India 4: 687. 1885; V.Singh in J. Econ. Tax. Bot., Add. Ser. 20: 152. 2001.

Leucas ciliata Benth. var. angustifolia (Hook.f.) Sunojk. in Candollea 63(1): 83.2008.

Leaves narrowly elliptic-lanceolate, up to $1.5 \mathrm{~cm}$ wide; bracts as long as calyx. Calyx teeth two-third as long as tube; mouth with a definite ring of villi.

Distribution: Endemic to India (Tamil Nadu \& Kerala) (Image 1).

Flowering \& Fruiting: November-February.

Representative specimen: India: Kerala, Sisparah, Wight s.n. (holo.:E).

11. Leucas vestita Wall. ex Benth. var. devicolamensis Shetty \& Vivek. in Bull. Bot. Surv. India 10: 236. f. 1-12. 1969; V. Singh in J. Econ. Tax. Bot., Add. Ser. 20: 152. 2001.

Leaves ovate or broadly ovate, $1.5-3 \mathrm{~cm}$ wide, serrate; bracts as long as calyx. Calyx mouth truncate, villous within; villi longer than calyx teeth.

Distribution: Endemic to India (Kerala) (Image 1).

Flowering \& Fruiting: August-December.

Representative specimens: India: Kerala, Kottayam, Devicolam, Upper vagavurrai, 11.viii.1967, Shetty \& Vivekananthan 28372 A (holo.: CAL); Shetty \& Vivekananthan 28372 B-S (iso.: MH) (Images 2 C,D).

12. Leucas vestita Wall. ex Benth. var. sericostoma Hook.f., Fl. Brit. India 4: 687. 1885; V. Singh in J. Econ. Tax. Bot., Add. Ser. 20: 155. 2001.
Leaves ovate-lanceolate or lanceolate, bracts as long as calyx. Calyx mouth villous within; teeth shorter than villi.

Distribution: Endemic to India (Tamil Nadu) (Image 1).

Flowering \& Fruiting: October-February.

Representative specimen: India, Anamalai hills, R.H. Beddome s.n. (holo.:BM). (Image 3A)

Efforts have been made to re-collect Leucas decemdentata var. angustifolia from its type locality in two seasons, but without success. Further explorations would be made in type localities and other possible habitats of these rare taxa of the genus Leucas to re-locate them. During the course of study, habitat destruction and deforestation have been identified as the main causes of threat.

The above mentioned taxa have been collected either once or twice and are known only by their type collections; therefore, it is urgently needed to make collections from the type locality, so that the size of population and conservation status can be ascertained. Medicinal values of other species of the genus Leucas are already known, and are considered as medicinal genus with immense potential, thus, screening for the medicinal or other economical value of these rare taxa will be of immense importance. Thus, first of all recollection of these rare taxa is very important because some taxa would disappear, if they have not already, due to destructive harvesting practices and habitat degradation, before screening of these endemic taxa can take place.

\section{References}

Chouhan, S.H. \& S.K. Singh (2011). A review of plants of genus Leucas. Journal of Pharmacognosy and Phytotherapy 3(3): 13-26.

Hooker, J.D. (1885). The Flora of British India - 4. Reeve \& Co., London, 680-691pp.

Jain, S.K. \& A.R.K. Shastry (1984). The Indian Plant Red Data Book - 1. Botanical Survey of India, Howrah

Mukerjee, S.K. (1940). A revision of the Labiatae of Indian Empire. Records of Botanical Survey of India 14(1): 1-228.

Nayar, M.P. \& A.R.K. Shastry (1987, 1988, 1990). Red Data Book of Indian plants I-III. Botanical survey of India, Calcutta.

Sebald, O. (1980). Die Gattung Leucas R. Br. (Labiatae) in Afrika und auf der Arabischen Halbinsel. Stuttgarter Beitr. Naturk., Ser. A. 341: 1-200.

Singh, V. (1998). Critical taxonomic notes on Leucas R. Br. Journal of Economic and Taxonomic Botany 22(2): 388.

Singh, V. (2001). Monograph on Indian Leucas R.Br. (Dronapushpi) Lamiaceae. In: Journal of Economic and Taxonomic Botany Add. Ser. 20. Scientific Publishers (India), Jodhpur.

Sunojkumar, P. \& P. Mathew (2002). Leucas beddomei (Hook. f.) Sunojkumar \& P. Mathew (Lamiaceae); a new status and name for Leucas hirta var. beddomei Hook. f. - a little known endemic from India. Rheedea 12(2): 169-174.

Umamaheswari, P. \& P. Daniel (1999). Leucas anandaraoana (Lamiaceae) - a new species from southeastern India. Kew Bulletin 54: 1003-1005. 